\title{
Physico-chemical properties of common beans under natural and accelerated storage conditions
}

\author{
Silvia R. M. Coelho', Sandra H. Prudencio², Divair Christ ${ }^{1}$, Silvio C. \\ Sampaio ${ }^{1}$, and Vanderleia Schoeninger ${ }^{1}$ \\ Program in Agricultural Engineering - PGEAGRI, Universidade Estadual do Oeste do Paraná, Postal Code \\ 85819-110, Cascavel, Paraná, Brazil. \\ ${ }^{2}$ Program in Food Science, Universidade Estadual de Londrina, PO Box 6001. Londrina, PR, Brazil.
}

\begin{abstract}
S.R.M. Coelho, S.H. Prudencio, D. Christ, S.C. Sampaio, and V. Schoeninger. 2013. Physico-chemical characterization of common beans under natural and accelerated storage conditions. Cien. Inv. Agr. 40(3): 629-636. The common bean is an important food in the human diet. Certain storage conditions, high temperatures and high humidity, cause a texture defect that reduces the acceptability of common beans. The present study aimed at evaluating the effect of storage on the physico-chemical properties of common bean grains and the relationship between accelerated aging at $40{ }^{\circ} \mathrm{C}$ and $76 \% \mathrm{RH}$ and storage under natural conditions. Two varieties of common beans (Iapar 81 - carioca variety and Iapar 44 - black variety) were stored at $40{ }^{\circ} \mathrm{C}$ and $76 \%$ RH for $15,30,45,60$ and 75 days to accelerate aging. The same varieties were stored under environmental conditions (natural aging) for 3, 6, 9 and 12 months. For both storage conditions of each variety, fresh beans stored at $5{ }^{\circ} \mathrm{C}$ were used as a control group. In all of the samples, hardness, $\mathrm{pH}$, acidity and the soluble protein percentage were analyzed. Both storage processes, in the natural and accelerated conditions, caused an increase in acidity ( 4.0 to 5.9 and 3.2 to $6.4 \mathrm{~g}$ acetic acid kg-1) and a decrease in cellular pH (6.65 to 6.45 and 6.65 to 6.45 ) and protein solubility ( 77 to 54 and 76 to $38 \%$ ). The greatest percentage changes in the parameters of acidity, $\mathrm{pH}$ and soluble proteins were observed in the beans in the accelerated aging condition. Beans' hardness during storage has a negative correlation with $\mathrm{pH}$, which shows that it is a good indicator of grain quality. Natural storage for one year is equivalent to accelerated aging for 45 days at $40{ }^{\circ} \mathrm{C}$ and $76 \% \mathrm{RH}$.
\end{abstract}

Key words: Food technology, cooking time, Phaseolus vulgaris, protein.

\section{Introduction}

The common bean is a traditional food in the human diet because it is a good source of protein, minerals and vitamins, polyunsaturated fatty acids and carbohydrates. The protein content ranges

Received March 13, 2013. Accepted October 25, 2013. Corresponding author: silvia.coelho@unioeste.br from 19 to $26 \%$, with some varieties reaching values up to $36 \%$; the lipid content ranges from 1 to $5 \%$, depending on the variability of the nutrients in the soil and the weather. The mineral content of beans is also high; in particular, there are $100 \mathrm{mg}$ of iron per kilo of beans (Amir et al., 2007; Mesquita et al., 2007; Wang et al, 2010; Siddiq et al., 2010). 
Fatty acids are vulnerable to oxidation, and the production of oxidized compounds can affect texture during grain storage (Sawazaki et al., 1985; Martin-Cabrejas et al., 1997; Yuan et al., 2002; Del Pino and Lajolo, 2003; Freitas et al., 2004; Pujola et al., 2007). While beans are stored, the grain quality deteriorates, caused by an irreversible and cumulative phenomenon, the intensity of which depends on various factors, such as temperature and relative humidity $(\mathrm{RH})$ (Rios et al., 2002). The stored grains of this leguminous species show a decrease in physiological quality and tend to brown, especially the carioca variety. There is also an increase in hardness and cooking time - factors that can lead to a reduction in consumption (Rios et al., 2002; Faroni et al., 2006; Resende et al., 2008; Coelho et al., 2009; Tertuliano et al. 2009; Nasar-Abbas et al., 2009; Oliveira et al., 2011).

High temperature and high relative humidity during storage accelerates the hardening of the grains as a result of a tissue problem known as hard-to-cook (HTC). This effect causes changes, such as an increase in the cooking time required for cotyledon softening resulting in lower acceptance by consumers and a decrease in nutritional value caused by the loss of vitamins, essential amino acids and seed availability (Sawazaki et al., 1985; Reyes-Moreno and Paredes-Lopez, 1993; Shiga et al., 2005). There are many explanations for the HTC phenomenon, including the production of insoluble pectates, the lignification of the middle lamella, oxidation or lipid polymerization, crossed links of denatured proteins and/or polyphenol radicals, pectin degradation, protein denaturation and multiple mechanisms (Reyes-Moreno and Paredes-Lopez, 1993; Shiga et al., 2005).

The decrease in $\mathrm{pH}$ can cause protein denaturation, resulting in a gradual decrease of the water solubility and the thermal stability of proteins during storage, which can be associated with the production of acids and other compounds produced by the decomposition of hydroperoxide (Sawazaki et al., 1985; Liu et al., 1992; MartínCabrejas et al., 1997).

Several storage methodologies are applied to speed up grain aging in order to study these changes (Henteges et al., 1991; Shiga et al., 2005; Ribeiro et al., 2005; Rocha-Guzman et al, 2006; Granito; Paolini and Perez, 2008). However, there are no standards for temperature or relative humidity and there are no correlational studies based on conditions during accelerated aging that correspond to conventional storage. Thus, this trial studied the effect of storage on the physico-chemical properties of common beans and the association between the accelerated aging of grains at $40{ }^{\circ} \mathrm{C}$ and $70 \%$ of RH and conventional storage under natural conditions.

\section{Materials and methods}

\section{Samples}

In the experiment, grains of black (Iapar 44) and carioca (Iapar 81) varieties of common beans (Phaseolus vulgaris L.) were used. The control group of each variety was stored at $5{ }^{\circ} \mathrm{C}$ for 12 months. The grains were stored under two different conditions (aging methods): an accelerated aging condition, with the samples stored at $40{ }^{\circ} \mathrm{C}$ with $76 \% \mathrm{RH}$ (obtained from a saturated solution of sodium chloride) and collected at 15, 30, 45, 60 and 75 days; and a natural environmental condition, with the samples collected at three, six, nine and twelve months of storage. For the analysis of the parameters (except hardness), the collected samples were left to stand for $12 \mathrm{~h}$ at room temperature and were then ground and sieved in a 50-mesh sieve.

\section{Chemical and physical-chemical analysis}

For all of the samples, the lipid content (dichloromethane extraction by the Soxhlet method) and 
protein content (Kjeldahl analysis, $\mathrm{N} \times 6.25$ ) were determined using the standard method of Instituto Adolfo Lutz (2008). A hardness determination was used to evaluate the grains' texture: $10 \mathrm{~g}$ of grains were cooked for 25 minutes in $250 \mathrm{~mL}$ of distilled water at $100{ }^{\circ} \mathrm{C}$ in a covered beaker and chilled to room temperature $\left(20^{\circ} \mathrm{C}\right)$. Hardness was measured in whole grains using a TA-XT2i texture measurement device (Stable Micro Systems, Surrey UK) with $0.05 \mathrm{~N}$ of compression force at a constant speed of $2.0 \mathrm{~mm} \mathrm{~s}^{-1}$ (Coelho et al., 2009).

To determine $\mathrm{pH}, 1.000 \mathrm{~g}$ of the ground and sieved sample was added to $50.00 \mathrm{~mL}$ of distilled water. The mixture was stirred for two minutes, and $\mathrm{pH}$ was immediately measured (Zimmermann et al., 2009). For the determination of protein solubility in cellular $\mathrm{pH}, 1.00 \mathrm{~g}$ of powder and $50.00 \mathrm{~mL}$ water were added while the mixture was mechanically stirred for two minutes. An aliquot of supernatant was used to determine the protein content according to the LOWRY method (Instituto Adolfo Lutz, 2008) using spectrophotometry at $660 \mathrm{~nm}$. The percentage of soluble protein was calculated based on the total protein content.

\section{Statistical analysis}

The experiment was carried out using a randomized block design (RBD). For each aging method (accelerated and natural) in a slip-plot design, the treatments were the aging periods (days or months, considered as plots), while the black and carioca bean varieties were the sub-plots. The results were submitted to analysis of variance (ANOVA) tests and $\mathrm{F}$ tests according to Snedecor's method. After the analysis of variance, the means were submitted to regression analyses, with $\mathrm{P} \leq 0.05$. The analyses of variance and the regression analysis were carried out using ESTAT software (Jaboticabal, São Paulo, Brazil) - a system for statistical analyses - V. 2.0 (Universidade Estadual Paulista, 1991).

\section{Results}

When the storage conditions were at $40{ }^{\circ} \mathrm{C}$ and $76 \%$ relative humidity (Table 1 ), the control grains had higher lipid content than the beans with other storage times. For the beans that aged naturally in environmental conditions (Table 2), the black

Table 1. Lipid and protein content of black and carioca beans aged at $40{ }^{\circ} \mathrm{C}$ and $76 \%$ relative humidity for 75 days.

\begin{tabular}{|c|c|c|c|c|c|c|c|}
\hline \multirow[b]{2}{*}{ Variety } & \multicolumn{6}{|c|}{ Storage time (days) } & \multirow{2}{*}{$\begin{array}{c}\text { Mean } \\
\mathrm{RSD}_{\text {var. }}=1.49 \%\end{array}$} \\
\hline & 0 & 15 & 30 & 45 & 60 & 75 & \\
\hline \multicolumn{8}{|l|}{$\%$ Protein $(d b)$} \\
\hline Carioca & 21.24 & 21.36 & 21.03 & 21.07 & 20.90 & 21.09 & $21.12 \mathrm{~A}$ \\
\hline Black & 22.37 & 22.30 & 22.86 & 22.61 & 22.38 & 22.38 & $22.46 \mathrm{~A}$ \\
\hline Mean & $21.80 \mathrm{a}$ & $21.83 \mathrm{a}$ & $21.94 \mathrm{a}$ & $21.77 \mathrm{a}$ & $21.64 \mathrm{a}$ & $21.74 \mathrm{a}$ & \\
\hline \multicolumn{8}{|c|}{$\mathrm{RSD}_{\text {time }}=1.37 \%$} \\
\hline \% Lipids (db) & & & & & & & $\mathrm{RSD}_{\text {var. }}=9.74 \%$ \\
\hline Carioca & $4.93 \mathrm{aB}$ & $3.04 \mathrm{bA}$ & $2.53 \mathrm{bA}$ & $2.60 \mathrm{bA}$ & $2.25 \mathrm{bA}$ & $2.58 \mathrm{bA}$ & 2.99 \\
\hline Black & $4.92 \mathrm{aA}$ & $2.37 \mathrm{bA}$ & $1.89 \mathrm{bA}$ & $1.52 \mathrm{bB}$ & $1.40 \mathrm{bA}$ & $1.41 \mathrm{bB}$ & 2.42 \\
\hline Mean & 5.43 & 2.70 & 2.22 & 2.06 & 1.83 & 2.00 & \\
\hline \multicolumn{8}{|c|}{ RSD time $=5.74 \%$} \\
\hline
\end{tabular}

Means in the same column that are followed by different upper case letters and values in the same row that are followed by different lower case letters, for each component, are significantly different according to Tukey's test $(\mathrm{P} \leq 0.05)$.

$\mathrm{RSD}=$ relative standard deviation (\%) of storage time (time) and variety (var.). 
Table 2. Lipid and protein content of black and carioca beans naturally aged in storage for twelve months.

\begin{tabular}{|c|c|c|c|c|c|c|}
\hline \multirow[b]{2}{*}{ Variety } & \multicolumn{5}{|c|}{ Storage time (days) } & \multirow{2}{*}{$\begin{array}{c}\text { Mean } \\
\mathrm{RSD}_{\text {var. }}=3.24 \%\end{array}$} \\
\hline & 0 & 3 & 6 & 9 & 12 & \\
\hline \multicolumn{7}{|c|}{$\%$ Protein $(\mathrm{db})$} \\
\hline Carioca & 21.07 & 20.88 & 21.28 & 21.40 & 21.37 & $21.19 \mathrm{~A}$ \\
\hline Black & 21.44 & 22.13 & 22.46 & 21.90 & 22.17 & $22.01 \mathrm{~A}$ \\
\hline \multirow[t]{2}{*}{ Mean } & $21.25 \mathrm{a}$ & $21.50 \mathrm{a}$ & $21.87 \mathrm{a}$ & $21.65 \mathrm{a}$ & $21.74 \mathrm{a}$ & \\
\hline & & & $\mathrm{RSD}_{\text {time }}=1.85$ & & & $\mathrm{RSD}_{\text {var. }}=3.99 \%$ \\
\hline \multicolumn{7}{|c|}{ \% Lipids (db) } \\
\hline Carioca & $4.62 \mathrm{abB}$ & $4.15 \mathrm{bB}$ & $4.81 \mathrm{aA}$ & $2.76 \mathrm{cA}$ & $1.95 \mathrm{dA}$ & 3.66 \\
\hline Black & $4.23 \mathrm{aA}$ & $4.16 \mathrm{aA}$ & $2.05 \mathrm{bB}$ & $1.87 \mathrm{bB}$ & $1.27 \mathrm{cB}$ & 3.51 \\
\hline \multirow[t]{2}{*}{ Mean } & 5.42 & 5.15 & 3.43 & 2.31 & 1.61 & \\
\hline & & & $\mathrm{RSD}_{\text {time }}=4.71 \%$ & & & \\
\hline
\end{tabular}

Means in the same column that are followed by different upper case letters and values in the same row that are followed by different lower case letters, for each component, are significantly different according to Tukey's test $(\mathrm{P} \leq 0.05)$.

RSD - relative standard deviation (\%) of storage time (time) and variety (var.).

variety had higher lipid content compared with the carioca variety of beans, which experienced a significant decrease in lipid content. Storing the grains caused some decrease in the lipid content of the analyzed samples.

The $\mathrm{pH}$ of stored beans, under accelerated and natural aging conditions, decreased with storage time (Figure 1a and 1b). It can be observed that the $\mathrm{pH}$, represented by the $\mathrm{b}$ parameter of the regression equation, declined at a faster rate in the carioca beans compared with the black variety in both aging processes. However, the initial $\mathrm{pH}$ of the carioca beans was higher than that of black beans.

According to the regression equations (Figure 1a and $1 b$ ), the $\mathrm{pH}$ value of the carioca beans after 12 months of storage is equivalent to the value at 31 days of accelerated aging. For the black variety, the $\mathrm{pH}$ value after 12 months corresponds to the value observed at nearly 35 days of storage at 40 ${ }^{\circ} \mathrm{C}$ and $76 \% \mathrm{RH}$ (relative humidity).

Because the HTC defect affects grains' hardness during storage, it was essential to study the correlation between $\mathrm{pH}$ and texture by measuring the hardness of beans aged under natural and accelerated aging conditions (Figure 2). There was a significant negative correlation between these parameters: a decrease in $\mathrm{pH}$ caused an increase in hardness for both bean varieties and both storage conditions.

The reduction in $\mathrm{pH}$ in stored beans is associated with an increase in acidity over storage time. In Figures 1c and 1d, it can be observed that the carioca variety beans had higher acidity than the black beans in both storage conditions. Slopes, represented by the b parameter (which indicates the speed of the increase in acidity with storage time), was similar for both varieties in both storage conditions in this study. The regression equations verified that the titratable acidity of carioca beans stored for 12 months was equivalent to the acidity of the beans stored for 44 days under accelerated aging conditions. For black beans, 12 months of storage was equivalent to 57 days of storage under accelerated aging conditions.

There was a strong decrease in the percentage of soluble proteins with storage time for both varieties and both aging methods (Figure 3). On the other hand, protein solubility decreased with storage 

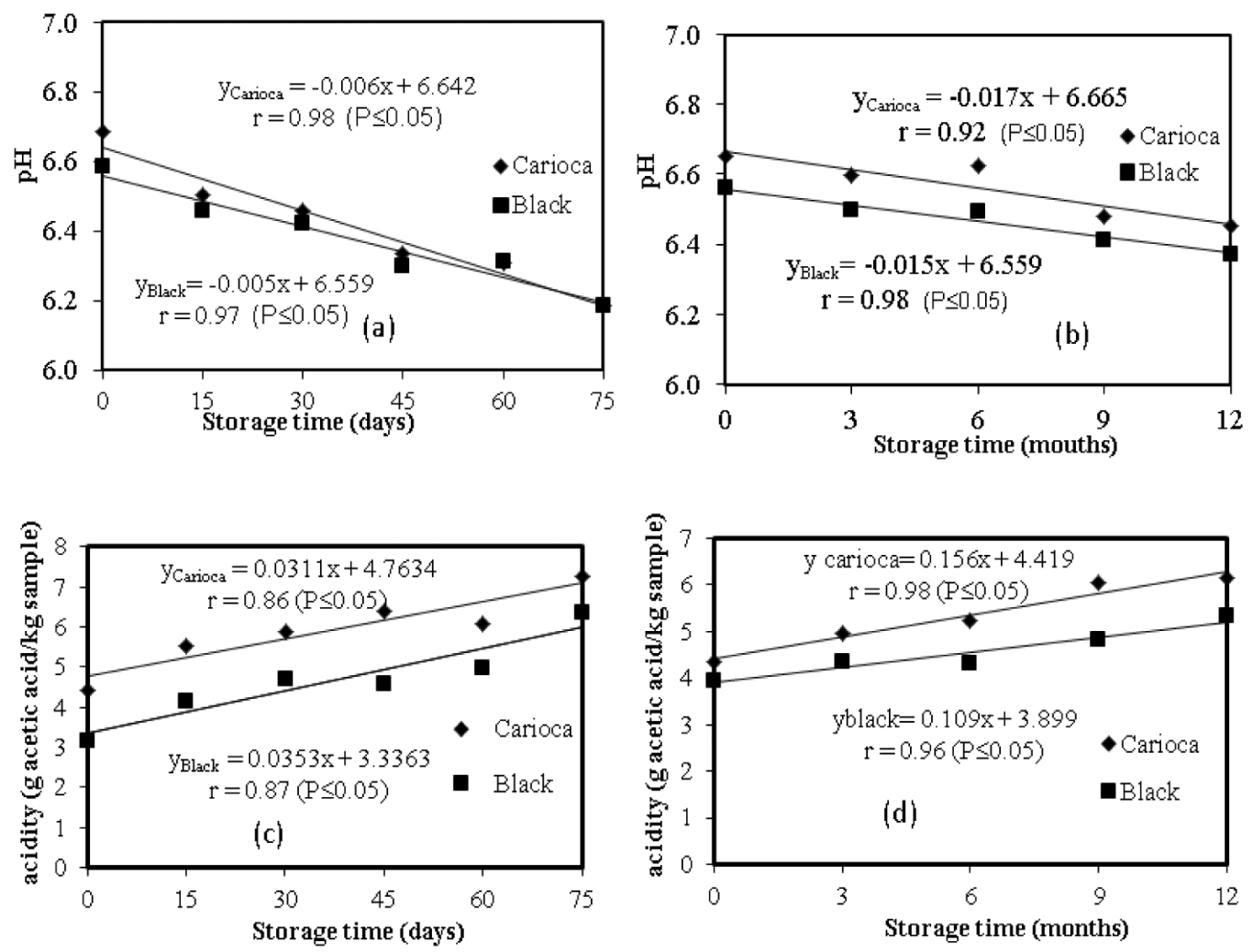

Figure 1. $\mathrm{pH}$ in water and the acidity ( $\mathrm{g}$ acetic acid. $\mathrm{kg}^{-1}$ of the sample) of carioca and black beans according to storage time at $40{ }^{\circ} \mathrm{C}$ and $76 \%$ relative humidity (a, c) and under natural temperature and relative humidity conditions (b, d).
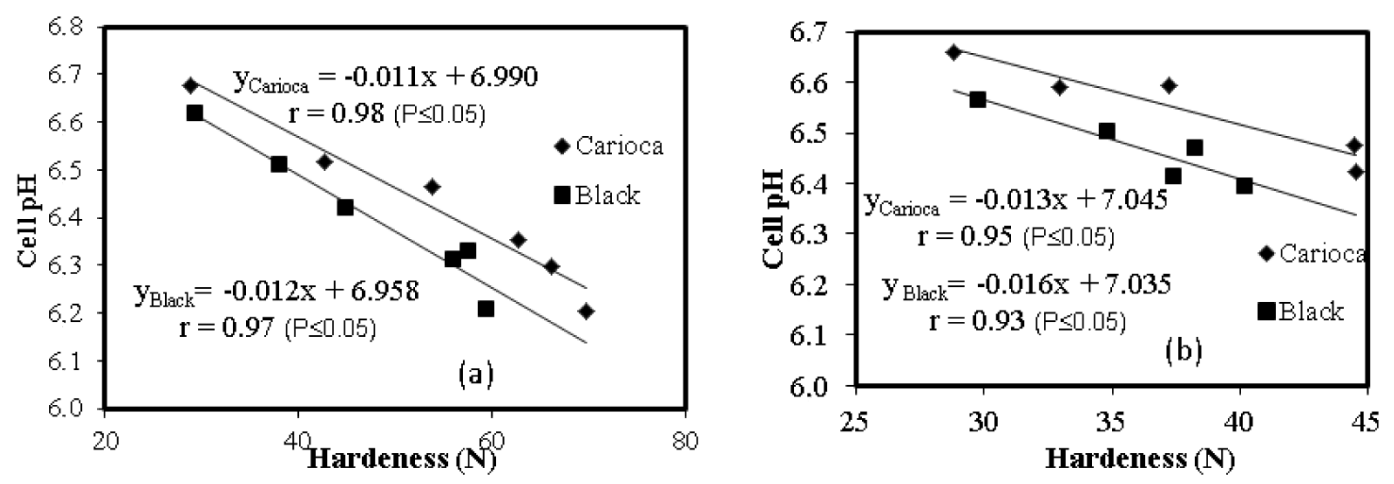

Figure 2. The relationship between the hardness and the cellular $\mathrm{pH}$ of carioca and black beans according to storage time at $40{ }^{\circ} \mathrm{C}$ and $76 \%$ relative humidity (a) and under natural temperature and relative humidity conditions (b).

time. In the regression equation shown in Figure 3 , it can be observed that the loss of solubility in the cellular $\mathrm{pH}$ was greater in carioca beans than in black beans using both the accelerated and the natural aging methods.
It can be noted that the percentage of soluble proteins in the carioca beans stored for 12 months was equivalent to the percentage in the beans stored for 44 days under accelerated aging conditions. On the other hand, for the black beans, the response 

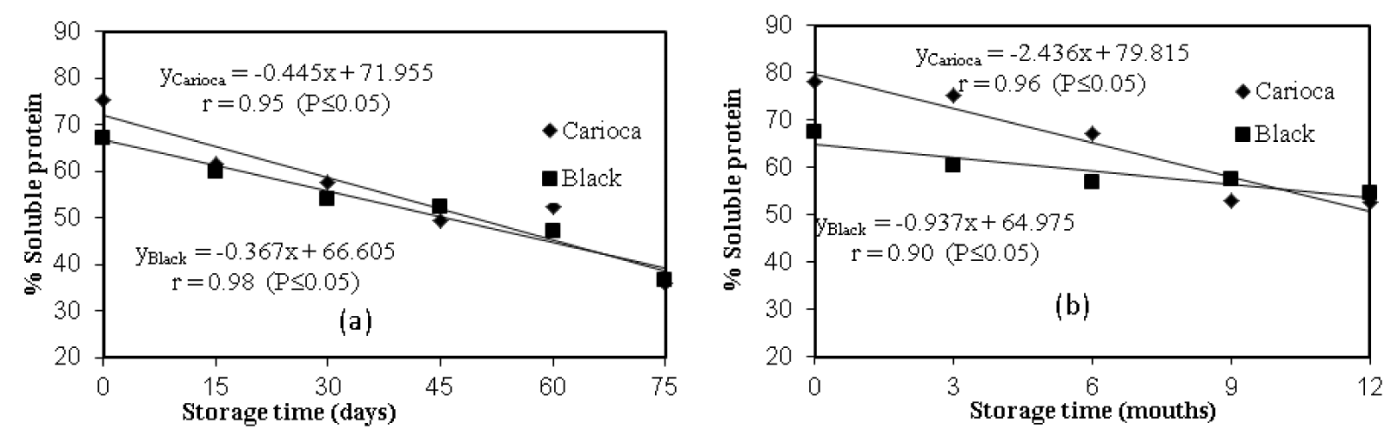

Figure 3. The percentage of soluble proteins in the cellular $\mathrm{pH}$ of carioca and black beans according to storage time at 40 ${ }^{\circ} \mathrm{C}$ and $76 \%$ relative humidity (a) and under natural temperature and relative humidity conditions (b).

after 12 months of storage was equivalent to the response after 33 days of storage under accelerated aging conditions.

\section{Discussion}

The lipid content of the beans was higher than the results reported by Mesquita et al. (2007) and Siddiq et al. (2010). However, a decrease in the lipid content of stored grains was also observed by other authors (Sawazaki et al., 1985; Ribeiro et al., 2005) and may be related to lipid oxidation, which generates products with higher solubility that are not quantified by the methodology applied in this analysis. The present study recorded a moderate decrease in the lipid content during storage, most likely as a result of fatty acid hydrolysis, which produces acidity and may be associated with the observed $\mathrm{pH}$ decrease.

In beans with the HTC defect, the decrease in the cellular $\mathrm{pH}$ lowers the solubility and the thermal stability of proteins, denaturing them during storage. This process results in restricted gelatinization during cooking time and an increase in bean hardness (Liu et al., 1992; Martin-Cabrejas et al., 1997). Zimmermann et al. (2009) reported lower $\mathrm{pH}$ values in beans that showed a greater loss of soluble solids, which is a parameter associated with aging in beans.

Martin-Cabrejas et al. (1997) studied the HTC defect in varieties of beans stored for five years and observed a decrease in $\mathrm{pH}$, but there was an increase in titratable acidity with storage time in all of the studied varieties. This result corroborates the results of the present study. As a result of the association between $\mathrm{pH}$ and tissue acidity and the significant correlation with bean texture, tissue $\mathrm{pH}$ is highly indicative of the HTC defect, and it is an easy parameter to measure.

Denaturation may have occurred because of the increase in acidity that was observed during storage in both studied varieties. This result has also been observed by other authors (Hentges et al., 1991; Ribeiro et al., 2005). Moreover, the low protein solubility found in beans is due to a secondary structure of the beta-sheet protein found in this leguminous species, which becomes more insoluble when heat is applied (Carbonaro et al., 2008); it may also be associated with the production of insoluble aggregates during storage.

The decrease in protein solubility during the aging process may be associated with the decrease in the tissue $\mathrm{pH}$ and may partially contribute to the development of the HTC defect, which results in hardness during bean storage. Storage under environmental conditions for one year corresponded to a maximum of 45 days under storage conditions at $40{ }^{\circ} \mathrm{C}$ and $76 \% \mathrm{RH}$ in terms of the analyzed parameters, except for acidity in black beans. 


\section{Resumen}

S.R.M. Coelho, S.H. Prudencio, D. Christ, S.C. Sampaio y V. Schoeninger. 2013. Caracterización físico-química de los granos de frijol común en condiciones de almacenamiento natural y acelerada. Cien. Inv. Agr. 40(3): 629-636. El frijol es un alimento importante en la dieta humana, cuyas condiciones de almacenamiento de alta temperatura y humedad provocan un defecto textural que reduce la aceptabilidad del frijol. El presente estudio tiene como objetivo evaluar el efecto de los métodos de almacenamiento a las propiedades físicoquímicas de los granos de frijol común y la relación entre la aceleración del envejecimiento a $40{ }^{\circ} \mathrm{C}$ y $76 \%$ humedad relativa (HR) y el almacenamiento en condiciones naturales. Se almacenaron dos variedades de frijol común (IAPAR 81 - carioca variedad y IAPAR 44 - la variedad negro) a $40{ }^{\circ} \mathrm{C}$ y $76 \%$ HR durante $15,30,45,60,75$ días de envejecimiento acelerado. Las mismas variedades fueron almacenadas bajo condiciones ambientales (envejecimiento natural) durante 3, 6, 9 y 12 meses. Para ambas condiciones de almacenamiento de cada variedad, se almacenaron granos nuevos a $5{ }^{\circ} \mathrm{C}$, los que se consideraron como control. En todas las muestras, se analizó dureza, $\mathrm{pH}$, acidez y porcentaje de proteína soluble. En ambos almacenamientos se observó un aumento de la acidez (4.0 a 5.9 y 3.2 a 6.4 g de ácido acético $\left.\mathrm{kg}^{-1}\right)$ y una reducción del pH celular (6.65 a 6.45 y 6.65 a 6.45) y solubilidad de la proteína (77 a 54 y 76 a $38 \%$ ), para las condiciones naturales y acelerada, respectivamente. Los mayores cambios en los parámetros del porcentaje de acidez, $\mathrm{pH}$ y proteínas solubles se observaron en el frijol en el envejecimiento acelerado. La dureza de los granos durante el almacenamiento tiene una correlación negativa con el $\mathrm{pH}$, lo que señala que este es un buen indicador de la calidad del grano. El almacenamiento natural de frijol durante un año corresponde al envejecimiento acelerado de 45 días a $40^{\circ} \mathrm{C}$ y $76 \%$ humedad relativa.

Palabras clave: Phaseolus vulgaris, proteína, tecnología de alimentos, tiempo de cocción.

\section{References}

Amir, Y., A.L. Haennib, and A. Youyoua. 2007. Physical and biochemical differences in the composition of the seeds of Algerian leguminous crops. Journal of Food Composition and Analysis 20:466-471.

Carbonaro, M., P.B. Maselli, P.B. Dore, and A. Nucara. 2008. Application of Fourier transform infrared spectroscopy to legume seed flour analysis. Food Chemistry 108:361-368.

Coelho, S.R.M., S.H. Prudencio, L.H.P. Nóbrega, and C.F.R. Leite. 2009. Alterações no tempo de cozimento e textura dos grãos de feijão comum durante o armazenamento. Ciência e Agrotecnologia 33:539-544.

Faroni, L.R.A., I.C. Cordeiro, E.R. Alencar, A.F. Rozado, and W.M. Alves. 2006. Influência do conteúdo de umidade de colheita e temperatu- ra de secagem na qualidade do feijão. Revista Brasileira de Engenharia Agrícola e Ambiental 10:148-154.

Granito, M., P. Paolini, and S. Perez. 2008. Polyphenols and antioxidant capacity of Phaseolus vulgaris stored under extreme conditions and processed. LWT - Food Science and Technology 41: 994-999.

Hentges, D.L., C.M. Weaver, and S.S. Nielsen. 1991. Changes of selected physical and chemical components in the development of the hard-to-cook bean defect. Journal of Food Science 56:436442.

Instituto Adolfo Lutz. 2008. Métodos físico-químicos para análise de alimentos. Instituto Adolfo Lutz, São Paulo, Brazil. 1020 pp.

Liu, K., K.H. Mcwatters, and R.D. Phillips. 1992. Protein insolubilization and thermal destabilization during storage as related to hard-to-cook de- 
fect in cowpeas. Journal of the Science of Food and Agriculture 40:2483-2487.

Martin-Cabrejas, M.A., R.M. Esteban, P. Perez, G. Maina, and K.W. Waldron. 1997. Changes in physicochemical properties of dry beans (Phaseolus vulgaris L.) during long-term storage. Journal of Agriculture and Food Chemistry 45:32233227.

Mesquita, F.R., A.D. Corrêa, C.M.P. Abreu, R.A.Z. Lima, and A.F.B. Abreu. 2007. Linhagens de feijão (Phaseolus vulgaris L.): Composição química e digestibilidade protéica. Ciência e Agrotecnologia 31:1114-1121.

Nasar-Abbas, S.M., K.H.M. Siddique, J.A. Plummer, E.D. White, F.K. Harris, F. Dods, and M. D'antuono. 2009. Faba bean (Vicia faba L.) seeds darken rapidly and phenolic content falls when stored at higher temperature, moisture and light intensity. LWT - Food Science and Technology 42:1703-1711.

Oliveira, V.R., N.D. Ribeiro, S.M. Maziero, A. Cargnelutti Filho, and E. Jost. 2011. Qualidade para o cozimento e composição nutricional de genótipos de feijão com e sem armazenamento sob refrigeração. Ciencia Rural 41: 746-751.

Pujola, M., A. Farreras, and F. Casanas. 2007. Protein and starch content of raw, soaked and cooked beans (Phaseolus vulgaris L.). Food Chemistry 102:1034-1041.

Reyes-Moreno, C. and O. Paredes-Lopez. 1993. Hard-to-cook phenomenon in common beans a review. Critical Reviews in Food Science and Nutrition 33(3):227-286.

Ribeiro, H.J.S.S., S.H. Prudêncio-Ferreira, and D.T. Miyagui. 2005. Propriedades físicas e químicas de feijão comum preto, cv. Iapar 44, após envelhecimento acelerado. Ciência e Tecnologia de Alimentos 25:165-169.

Rios, A.O., C.M.P. Abreu, and A.D. Corrêa. 2003. Efeito da estocagem e das condições de colheita sobre algumas propriedades físicas, químicas e nutricionais de três cultivares de feijão (Phaseolus vulgaris L.). Ciência e Tecnologia de Alimentos 23:39-45.

Rocha-Guzmán, J.A., R.F. Gallegos-Infante, P.A. González-Laredo, E. Castillo-Antonio, F. Delgado-Licon, and A. Ibarra-Pérez. 2006. Functional properties of three common bean (Phaseolus vulgaris) cultivars stored under accelerated conditions followed by extrusion. LWT - Food Science and Technology 39:6-10.

Sawazaki, H.E., J.P.F. Teixeira, R.M. Moraes, and E.A. Bulisani. 1995. Modificações bioquímicas e físicas em grãos de feijão durante o armazenamento. Bragantia 44:375-3.

Shiga, T.M., F.M. Lajolo, and T.M.C.C. Filisetti. 2005. Changes in the cell wall polysaccharides during storage and hardening of beans. Food Chemistry 84:53-64.

Siddiq, L., R. Ravi, J.B. Harte, and K.D. Dolan. 2010. Physical and functional characteristics of selected dry bean (Phaseolus vulgaris L.). LWT Food Science and Technology 43:232-237.

Tertuliano, P.C., C.M.A. Souza, L.Z.L. Rafull, L.C.F. Souza, and A.D. Robaina. 2009. Qualidade de sementes de feijão colhidas por colhedora autopropelida em sistema semimecanizado. Engenharia Agrícola 29:81-90.

Universidade Estadual Paulista. 1991. Sistema para análises estatísticas: ESTAT. v.2.0. UNESP, Jaboticabal, São Paulo, Brazil.

Wang, N., D.W. Hatcher, R.T. Tyler, R. Toews, and E.J. Gawalko. 2010. Effect of cooking on the composition of beans (Phaseolus vulgaris L.) and chickpeas (Cicer arietinum L.). Food Research International 43: 589-594.

Zimmermann, L.O.G, S.R.M. Coelho, D. Christ, and L.H.P. Nóbrega. 2009. Alterações da qualidade tecnológica de marcas comerciais de feijão dos grupos cores e preto Semina: Ciências Agrárias 30:619-628. 